\title{
Geoelectric structure of northern Cambay rift basin from magnetotelluric data
}

\author{
Nagarjuna Danda ${ }^{1}$, C. K. Rao ${ }^{1 *}$ and Amit Kumar ${ }^{2}$
}

\begin{abstract}
Broadband and long-period magnetotelluric data were acquired over the northern part of the Cambay rift zone along an east-west profile $\sim 200 \mathrm{~km}$ in length. The decomposed TE- and TM-mode data were inverted using a 2-D nonlinear conjugate gradient algorithm to obtain the lithospheric structure of the region. A highly conductive ( $1000 \mathrm{~S})$ layer was identified within the Cambay rift zone and interpreted as thick Quaternary and Tertiary sediments. The crustal conductors found in the profile were due to fluid emplacement in the western part, and the presence of fluids and/or interconnected sulfides caused by metamorphic phases in the eastern part. The demarcation of the Cambay rift zone is clearly delineated with a steeply dipping fault on the western margin, whereas the eastern margin of the rift zone gently dips along the NE-SW axis, representing a half-graben structure. A highly resistive body identified outside the rift zone is interpreted as an igneous granitic intrusive complex. Moderately conductive (30-100 $\Omega-m)$ zones indicate underplating and the presence of partial melt due to plume-lithosphere interactions.
\end{abstract}

Keywords: Cambay rift zone, Deccan basalt, Lithosphere, Magnetotellurics, Reunion plume

\section{Introduction}

The western continental margin of India (WCMI) demonstrates its evolution through the mid-Cretaceous and Tertiary periods (Courtillot et al. 1988; White and McKenzie 1989; Storey et al. 1995; Bhattacharya and Chaubey 2001 and references therein). The structural architecture of the WCMI was also modulated by two major geodynamic events, the activity of the Reunion hotspot and the collision that formed the Indo-Eurasian continental plate. The interaction between the Reunion hotspot and the Indian continental lithosphere during the Cretaceous-Tertiary boundary ( $65 \mathrm{Ma}$ ago) resulted in a huge flood of basaltic eruptions, which formed the Deccan volcanic province (DVP) over the western and central Indian sub-continent (Raval and Veeraswamy 2000; Veeraswamy and Raval 2004). It covers an area of more than $500,000 \mathrm{~km}^{2}$, almost one-sixth of the total surface area of the Indian Peninsula. The eruption of the DVP by the Reunion hotspot has been inferred as late syn-rift-tobreakup volcanism contemporaneous with the separation

\footnotetext{
*Correspondence: ckrao@iigs.iigm.res.in; ckraochinta@gmail.com 1 Dr. K. S. Krishnan Geomagnetic Research Laboratory, IIG, Allahabad, India Full list of author information is available at the end of the article
}

of the Seychelles and India $\sim 65 \mathrm{Ma}$ ago. As the Indian plate started moving northward, the adjacent offshore areas were influenced by the Reunion hotspot, resulting in various magmatic intrusions within the stretched continental crust of the WCMI (Bhattacharya and Chaubey 2001; Chaubey et al. 2002; Royer et al. 2002). The region was uplifted around the impingement location of the hot mantle plume and developed a four-way radially deviating mega-fracture pattern. The roughly $\mathrm{N}-\mathrm{S}$ trending fractures produced further extensional stresses, eventually resulting in the breakup between the Seychelles and Indian plates along these fracture arms. The western continental margin then reactivated along the eastern parts of these extending fractures. The Narmada geofracture zone formed along the third arm, whereas the fourth arm resulted in the Cambay basin, due to extensional stresses associated with the separation and movement of the Indian plate away from the Seychelles. The second-stage rifting of the Cambay basin is considered to be coeval with the breakup of the Indian plate and the Seychelles as well as the eruption of Deccan basalts in the Late Cretaceous (Raval and Veeraswamy 2000; Veeraswamy and Raval 2004) by generating significant variations in volcanic intensity as observed in the Baikal rift zone, a Rio 
Grande rift system. Several geophysical studies were carried out to understand the tectonics, sediment thickness, and rifting processes of the Cambay basin (Kaila et al. 1990; Tewari et al. 1991, 1995; Mishra et al. 1998; Singh et al. 2003; Dixit et al. 2010; Kumar et al. 2016). Most authors have reported $\sim 1-5-\mathrm{km}$-thick Tertiary and Quaternary sediments, inferring that lower crustal magmatic underplating occurred associated with plume interaction and rifting events.

Though various geophysical studies have been carried out, information on the deeper structure across the basin is limited. The MT method has been successfully used in delineating deep crustal and upper mantle structures (Jones 1992; Gokarn et al. 2001; Rao et al. 2014b; Abdul Azeez et al. 2017), the presence of partial melts (Unsworth et al. 2005) and areas of magmatic underplating (Wannamaker et al. 2008) by studying the variations in the electrical resistivity of Earth's interior. Although several MT studies have been carried out to understand the resistivity structure of the Mesozoic rift basins at the western margin of India, and to delineate areas of magmatic underplating and intrusions in the rift zones induced by the Reunion plume (Rao et al. 2004; Naganjaneyulu and Santosh 2010; Abdul Azeez et al. 2013; Patro and Sarma 2016 and references therein), no studies have yet been made to image the deep resistivity structure across the Cambay rift. In order to decipher the deeper structure and sediment thickness in the northern part of the basin, an MT study was performed as shown in Fig. 1. The detailed modeling of the lithospheric geoelectric structure in the study region, combined with geodynamic and tectonic information, establishes a plausible deep crustal resistivity structure, increasing the understanding of evolutionary processes and the impact of the Reunion plume on the structure of the crust and mantle.

\section{Regional tectonic framework}

The WCMI is made up of the Kutch, Cambay and Narmada rift basins that developed during the breakup of the Indian continent from Gondwanaland during the Mesozoic era. These basins were formed by rifting along with the three major Precambrian tectonic trends of western India, Dharwar (NNW-SSE), Aravalli-Delhi (NE-SW) and Satpura (ENE-WSW), that controlled the tectonic style of the basins, and these rifting events were synchronous with the major events of Indian continental drifting history (Biswas 1982, 1987 and references therein). These trends can be seen as metamorphic belts, which represent the three major orogenic cycles. The Aravalli-Delhi and Dharwar trends represent the oldest orogenic cycle and are followed by the Satpura. The Narmada-Son lineament developed along the Satpura trend by dividing the Indian shield into two blocks. The NNW-SSE Dharwar trend swings eastwards and syncs with the ENE-WSW Precambrian orogenic trends. The extension of the NNW-SSE trend parallel to the WCMI in the western part of the peninsular Indian shield led to the formation of the Cambay basin during the Mesozoic period. Though the formation of the basin took place during the Mesozoic, the Cambay basin is named a Tertiary basin because of its higher rate of subsidence during the Tertiary. The NNW-SSE-trending Cambay rift basin extends from Barmer in the north to the offshore region in the south (Gupta 1981). Initially, the basin started rifting perpendicular to the eastern and western faults, which formed parallel to the axis of the basin. The rift is wider on its southern side and narrow in the northern Barmer and Sanchore regions. The NE-SW Aravalli-Delhi trend splits into three directional components in the western margin of India. The main NE-SW Aravalli trend continues across the Cambay basin into Saurashtra, while the Delhi trend swings E-W by forming a series of step faults, continuing into the Kutch basin. The third component bends counterclockwise and merges with the ENEWSW Satpura trend.

The Cambay basin is surrounded by the Precambrian Aravalli group of formations in the NE and is bounded by discontinuous faults, including Deccan traps in the east and west as shown in Fig. 1. Deccan volcanism dates to the Mesozoic era, near the Cretaceous-Tertiary boundary, and subdued early rifting by erupting thick Deccan basalts over the Cretaceous sediments, shaping the basin basement. Subsequently, the basin was filled with Tertiary and Quaternary sediments consisting of sandstone, siltstone, claystone, and shales. Biswas (1982) categorized the Cambay rift as a present-day active rift that continues to be a low-lying area. Due to the large sediment thickness, the Cambay basin has become one of the major hydrocarbon-producing sedimentary basins in India.

\section{Geophysical studies}

A large number of hydrocarbon exploration surveys have been carried out resulting in geological, geophysical, and well log data sets of the Cambay basin. Despite the availability of fairly good information on shallow depths along the rift basin, not much is known about its deeper structure, the sedimentary thickness over the northern region, or the presence of Mesozoic sediments beneath the Deccan basaltic basement. Initially, gravity surveys (Negi 1951; Qureshi 1964; Rao 1968) were carried out to study the basement structure and nature of subsurface formations. These studies revealed a high Bouguer gravity anomaly within the basin compared to the surrounding regions, inspiring a few studies (Tewari et al. 1991, 1995) to attempt to establish a relationship with Precambrian trends. Most studies attributed the high gravity to 


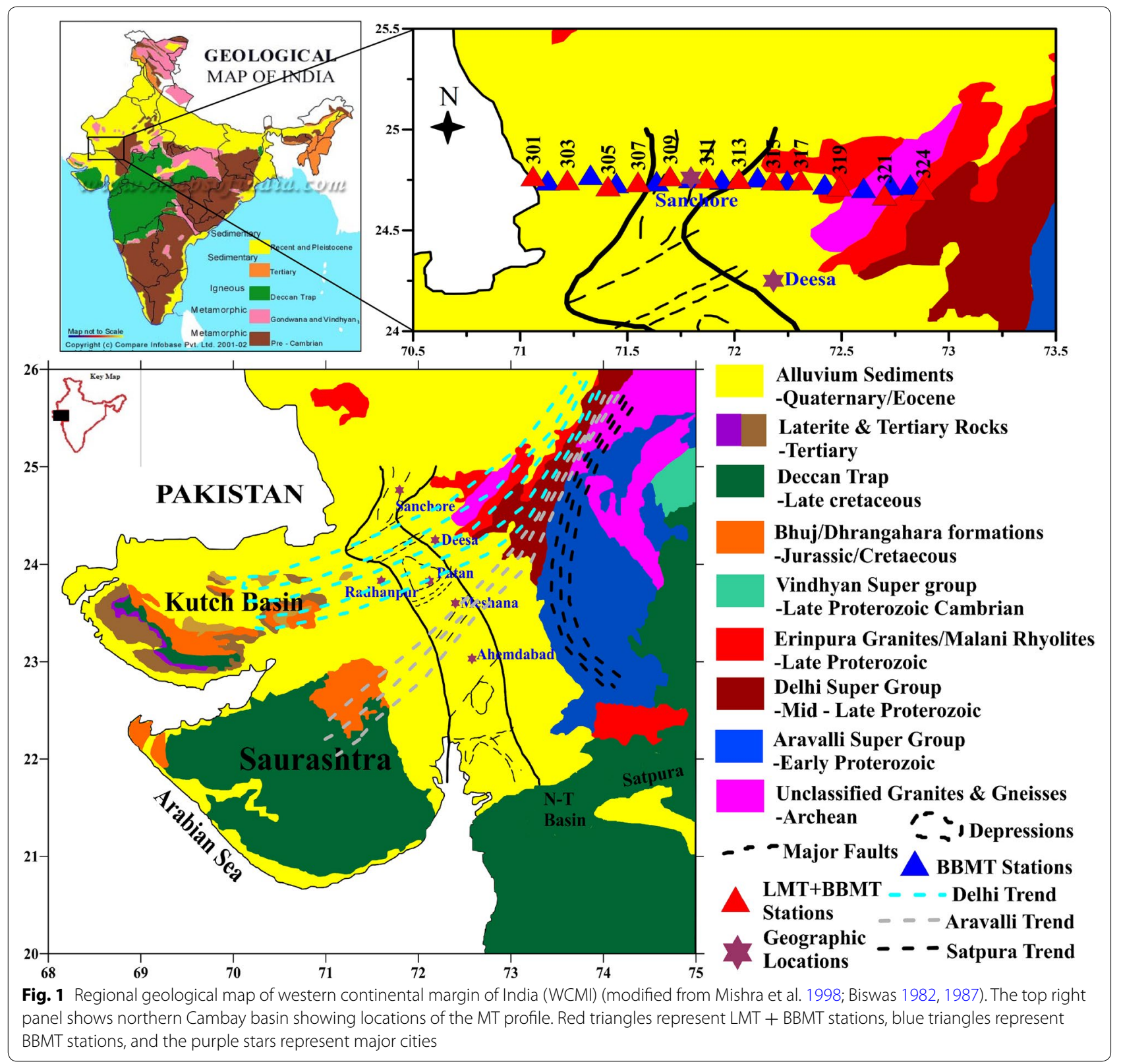

various features like a Moho upwarp accompanied by high-density lower crust, a large thickness of volcanic material within the basin, and intrusion from the upper mantle.

The extensive deep seismic sounding (DSS) studies carried out over the Cambay basin for hydrocarbon exploration (Kaila et al. 1990; Tewari et al. 1991, 1997; Dixit et al. 2010) revealed major structural trends in the basin and supported the explanation of magmatic underplating beneath the Kutch and Cambay rift basins. The Cambay basin is complex in nature, containing horst structures and $\mathrm{E}-\mathrm{W}$ directional faults that divide the basin into four sub-basins. DSS studies inferred (a) a basement depth of $\sim 2-7 \mathrm{~km}$ underneath the four sub-basins, (b) presence of a 2-3 km-thick, prominent low-velocity zone (5.5$5.8 \mathrm{~km} / \mathrm{s}$ ) within the upper crust at a depth of 10-12 km, (c) a high-velocity layer $(7.3-7.4 \mathrm{~km} / \mathrm{s})$ in the lower crust and Moho depth at 31-33 km. Mishra et al. (1998) carried out gravity surveys along a geotransect covering the Cambay and Narmada rift basins. Their study reported a sediment $2-3 \mathrm{~km}$ thick over the ridges, 5-6 km in the depressions of the Cambay rift basin, and a Moho depth of $31-32 \mathrm{~km}$. These DSS and gravity studies concluded that the presence of the high-velocity layer represents an 
underplating of the crust due to mantle upwarp during the Deccan volcanic eruption, and suggest that the region is an uplifted tectonic block. Due to the presence of this high-velocity layer of crust in the region of the WCMI, it is believed that the Reunion plume has affected its crustal portions. Plume interaction signatures have been traced through the Cambay basin to the immediate east of the Saurashtra peninsula (Campbell and Griffiths 1990).

Rao et al. (2015) analyzed near-surface shear velocities (NSV) using a network of permanent broadband stations over northwestern DVP. The Cambay basin region shows very small NSV values of $1.03-2.25 \mathrm{~km} / \mathrm{s}$, indicating the presence of sediments within the rift basin. This study inferred an average crustal thickness of $32.5 \mathrm{~km}$ and an average $V_{\mathrm{p}} / V_{\mathrm{s}}$ value of $\sim 1.67$, indicating a felsic crust. These results are also supported by DSS models (Kaila et al. 1981, 1990) and gravity studies (Singh et al. 2003).

Kaila et al. (1990) and Tewari et al. (1991) summarized that the crustal extension, mantle upwarp and continental rifting are related to Deccan volcanism and high-velocity lower crustal zones. Crustal thinning and the decrease in $V_{\mathrm{p}} / V_{\mathrm{s}}$ values are possibly related to crustal heating and its resulting structural differentiation (Negi et al. 1992). Studies of near-surface shear velocities (NSV) and boreholes drilled in the Cambay basin clearly support the deposition of Quaternary and Tertiary sediments, mainly sandstone, siltstone, claystone and shales, into different marine incursive, lacustrine environments, controlled by steep faults on its margins (Roy Chowdhury and Hargraves 1981; Biswas 1982, 1987; Mohan 1995).

Verma et al. (1968), Gupta et al. (1970) and Gupta (1981) carried out geothermal studies to correlate heat flow $\left(75-93 \mathrm{~mW} / \mathrm{m}^{2}\right)$ with basin tectonics, characterizing the Cambay basin as a high heat flow region. These studies attributed high heat flow to igneous intrusion beneath the crust from the Pliocene to Miocene and concluded that the central region is a relatively high heat flow zone. The bottom hole measurements from thermal studies (Panda and Dutta 1985; Sonam et al. 2013) between areas of active north-to-south subsidence also inferred higher $\left(20-75{ }^{\circ} \mathrm{C} / \mathrm{km}\right)$ geothermal gradients. Studies of teleseismic data across the Cambay rift zone (Kumar et al. 2016) reported that the presence of carbonated partial melt beneath it leads to $\mathrm{a} \sim 10 \%$ reduction in shear velocity. Thus, the velocity structure outlined implies a shallow lithosphere $\sim 60 \mathrm{~km}$ beneath and $\sim 110 \mathrm{~km}$ on either side of the rift zone, and suggesting that a now-inactive plume resulted in magma formation that thinned the lithosphere across the Cambay rift zone.

\section{MT data acquisition and processing}

Magnetotelluric data were acquired with two sets of instruments. Broadband magnetotellurics (BBMT) with period between 0.003 and $3000 \mathrm{~s}$ were obtained using a Phoenix Geophysics MTU-V5 system, and longperiod magnetotellurics (LMT) with period between 10 and 30,000 s were acquired using a LIMS system from LIVIV, a Ukraine firm. Data were acquired at 24 stations spaced $8-10 \mathrm{~km}$ apart along a profile, covering a total distance of $\sim 200 \mathrm{~km}$ in an $\mathrm{E}-\mathrm{W}$ direction between $71^{\circ} 03^{\prime} \mathrm{E}-72^{\circ} 52^{\prime} \mathrm{E}$ and $24^{\circ} 46^{\prime} \mathrm{N}-24^{\circ} 42^{\prime} \mathrm{N}$ across the northern part of the Cambay rift basin during 2014-2015. BBMT data were acquired at all 24 stations for $30-40 \mathrm{~h}$, and LMT data were acquired at 12 alternative BBMT stations for 18-22 days. Electric field variations were measured using nonpolarizable $\mathrm{Pb} / \mathrm{PbCl}$ electrodes arranged in orthogonal directions and having a dipole length of $60 \mathrm{~m}$. Magnetic field variations were measured using MTC-50 induction coil magnetometers at the BBMT stations and three-component ring core fluxgate magnetometers at the LMT stations. The BBMT time series data were processed using the robust remote reference technique of Jones and Jödicke (1984) and Jones et al. (1989). The LMT data were processed using the LEMIMT software package supplied by LIVIV. Where LMT data were available, the responses were merged with corresponding BBMT responses to obtain response estimates over periods between 0.003 and 30,000 s. For most of the stations, the data quality was acceptable, up to $1000 \mathrm{~s}$ for BBMT sites and 10,000 s for LMT sites. Unfortunately, due to unavoidable cultural noise sources at some LMT stations, long-period responses of more than $10,000 \mathrm{~s}$ were discarded due to poor data quality.

\section{Dimensionality and geoelectric strike}

The multi-site and multi-frequency decomposition approach of McNeice and Jones (2001) was applied to identify and analyze galvanic distortions and to determine the most appropriate geoelectric strike direction over the profile. The RMS error and galvanic distortion parameters obtained from the tensor decomposition are presented in Additional file 1: Fig. S1a, b, and the summary of geoelectric strike directions are shown in Fig. 2. The multi-site, multi-frequency analysis of the profile suggests that the regional strike is best defined in the direction $\mathrm{N}^{\circ} \mathrm{E}$ and $\mathrm{N} 50^{\circ} \mathrm{E}$ for the Cambay rift zone and Aravalli and Delhi formations of Precambrian age, respectively. The galvanic distortion parameters, twist $\left( \pm 10^{\circ}\right)$ and shear $\left( \pm 15^{\circ}\right)$, are much lower than the normal ranges for the stations covering both geological formations, indicating that the MT data contains only minor galvanic distortion. At some stations in the Cambay rift basin, the strike angle is $N 45^{\circ} \mathrm{E}$, due to the 1-D nature of the data, and during some periods the data is affected by strong noise. The noisy data from those periods were discarded prior to performing the 2-D inversion. The 


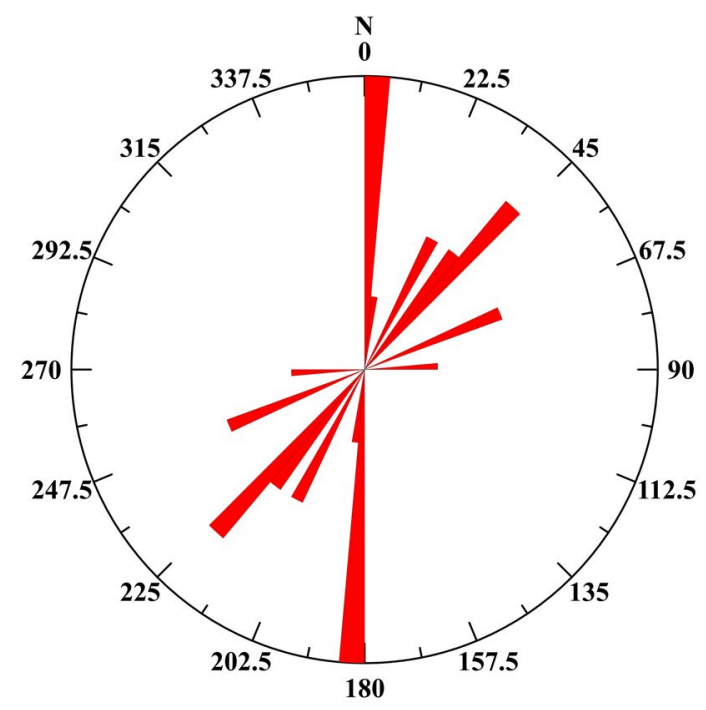

a $0.001-10000 \mathrm{Sec}$

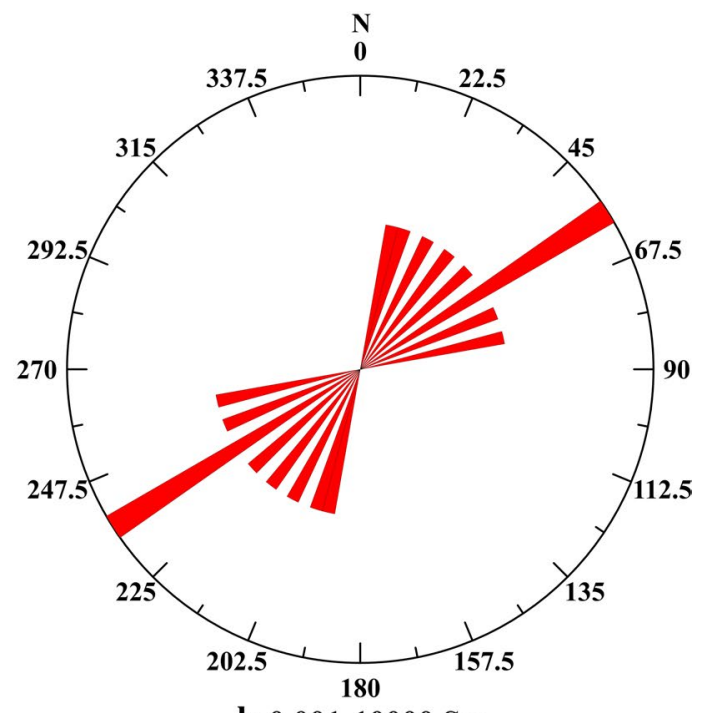

b 0.001-10000 Sec

Fig. 2 Rose diagrams showing regional geoelectric strike directions computed from McNeice and Jones (2001) for periods between 0.001 and 10,000 s. a For stations $301-315$ and $\mathbf{b}$ for stations $316-324$

distortion model best fits most of the stations, data with RMS error $<2$ for the two respective geoelectric strike directions. For station 316 at the eastern boundary of the Cambay rift zone, the RMS misfit is large, which may be due to current channeling at the edges of the geological bodies (Rao et al. 2014a). As a result of geoelectric strike estimation and galvanic distortion analysis, response estimates were derived for the 2-D MT modes, with TE and TM representing the current flow parallel and perpendicular to subsurface geoelectric strike direction, respectively. The strike direction obtained from this approach has a $90^{\circ}$ ambiguity, but local geology and induction arrows can be used to resolve it. The strike direction is consistent with major $\mathrm{N}-\mathrm{S}$ gravity trends in the Cambay basin and NE-SW trends in the Aravalli and Delhi formations. The real induction arrows, using the Parkinson convention where arrows point toward conductive anomalous zones, are plotted for the periods 1,10 , 100, 500, 1000 and $2500 \mathrm{~s}$ as shown in Fig. 3. Most of the induction arrows for short periods point toward the thick sediments deposited within the Cambay rift zone. The vectors at a period of $1000 \mathrm{~s}$, and at some stations, at periods of 500 and $2500 \mathrm{~s}$, are perpendicular to geoelectric strike directions estimated using the McNeice and Jones algorithm. The randomness in the direction of the induction arrows in the Cambay rift basin may be attributed to a variation in thickness of the sediments and errors arising from measurement of the vertical magnetic field. The vertical magnetic field data for all periods from the 310, 314, and 316 stations, and selected periods for some stations, removed due to strong noise. After resolving the $90^{\circ}$ ambiguity, the $\mathrm{MT}$ impedances were rotated into $\mathrm{N} 5^{\circ} \mathrm{E}$ for the stations $301-315$ and $\mathrm{N} 50^{\circ} \mathrm{E}$ for stations 316-324 to generate TE (parallel to strike) and TM (perpendicular to strike) modes. The tensor-decomposed regional impedances of TE- and TM-mode data for a few stations are shown as apparent resistivity and phase curves in Fig. 4.

\section{Depth of penetration}

The Niblett-Bostick depth approximation (Niblett and Sayn-Wittgenstein 1960; Bostick 1977; Jones 1983) was applied to the profile dataset to estimate the maximum penetration depth at each site. This approach is based on a 1-D approximation from the method and is strictly valid only if 2-D transverse electric (TE) and transverse magnetic (TM) modes are fully decoupled in the orthogonal directions and penetrate to the same depth as 1-D signals (Jones 2006). The validity of this approach to estimating the penetration depth of two orthogonal modes is approximate, especially where the TM and TE modes may not be completely decoupled due to 3-D effects at regional scale, but, nevertheless, it is superior to a periodbased analysis. Figure 5 illustrates the variation of penetration depth for the orthogonal TE and TM modes at stations across the entire profile. The penetration depth is shallower in the Cambay rift basin due to thick conductive sediments, whereas it is much deeper across the Precambrian group of Aravalli and Delhi formations due to the presence of highly resistive rocks at crustal depths. The maximum penetration depth is $\sim 100 \mathrm{~km}$ over the Cambay rift basin and $>500 \mathrm{~km}$ over the Precambrian 

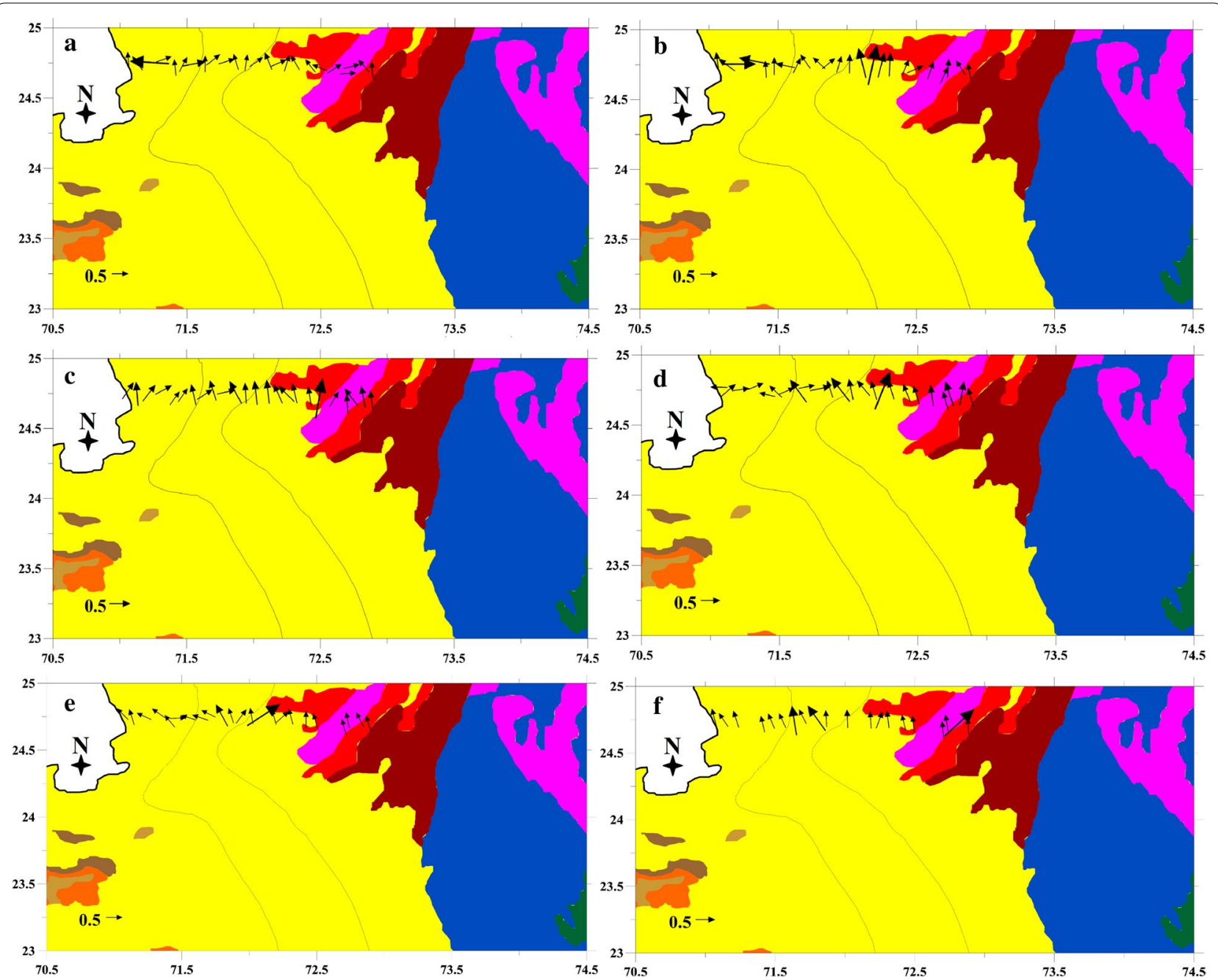

Fig. 3 Real induction arrows (Parkinson convention) at different periods. a 1 s, b 10 s, c, 100 s, d 500 s, e 1000 s and f 2500 s. See text for explanation

Aravalli and Delhi formations. By considering the penetration depths across the entire profile, the structure and features of lithospheric resistivity can be adequately imaged.

\section{Two-dimensional inversion}

The decomposed TE- and TM-mode responses were inverted using the 2-D inversion algorithm of Rodi and Mackie (2001) as implemented within the WinGLink software package of Schlumberger/WesternGeco. This algorithm searches for the smoothest model from a homogeneous half-space by attempting to iteratively determine the best fit of the observed data with the squared Laplacian, a smoothing term, of the horizontal and vertical resistivity gradients (Mackie and Madden 1993). Unreliable data points, with large scatter and error bars, were removed from the dataset prior to 2-D inversion. The starting model of the homogeneous half-space was a mesh containing 84 rows and 256 columns and having a uniform resistivity of $100 \Omega-\mathrm{m}$. The data were assigned an error floor of $10 \%\left(2.9^{\circ}\right)$ and $5 \%\left(1.45^{\circ}\right)$, for phases 15 and 10\%, for the TE- and TM-mode resistivities, respectively. The tipper data were included in the inversion scheme after 70-100 iterations. The absolute error for the tipper data was set to 0.025 in the inversion scheme. The smoothing parameters alpha and beta were set to be 1 , and block dimensions of $500 \mathrm{~m}$ and $1000 \mathrm{~m}$ were assigned for the horizontal and vertical gradients, respectively. Different models were generated with various combinations of data, including the TE and TM modes and the vertical transfer function, and uniform grid Laplacians with different smoothing operators starting from 100 to 1 at different orders were used. In the 2-D inversion algorithm, the regularization parameter $\tau$ plays a key role in controlling the optimization between data fit and roughness of the model. In order to 

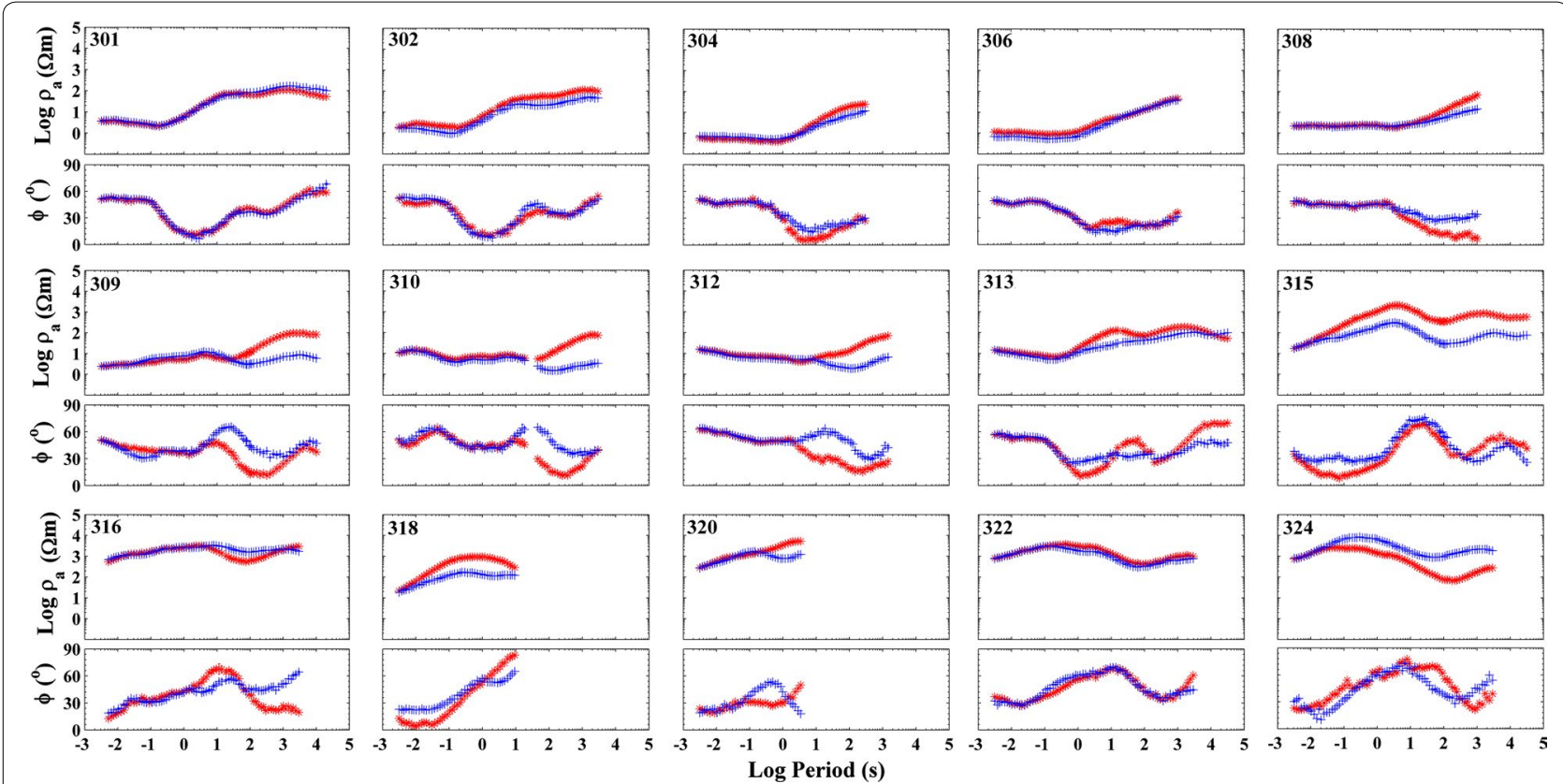

Fig. 4 Apparent resistivity and phase curves for representative stations of data used in 2D inversion. Blue color + represents TM mode and red color * represents TE mode

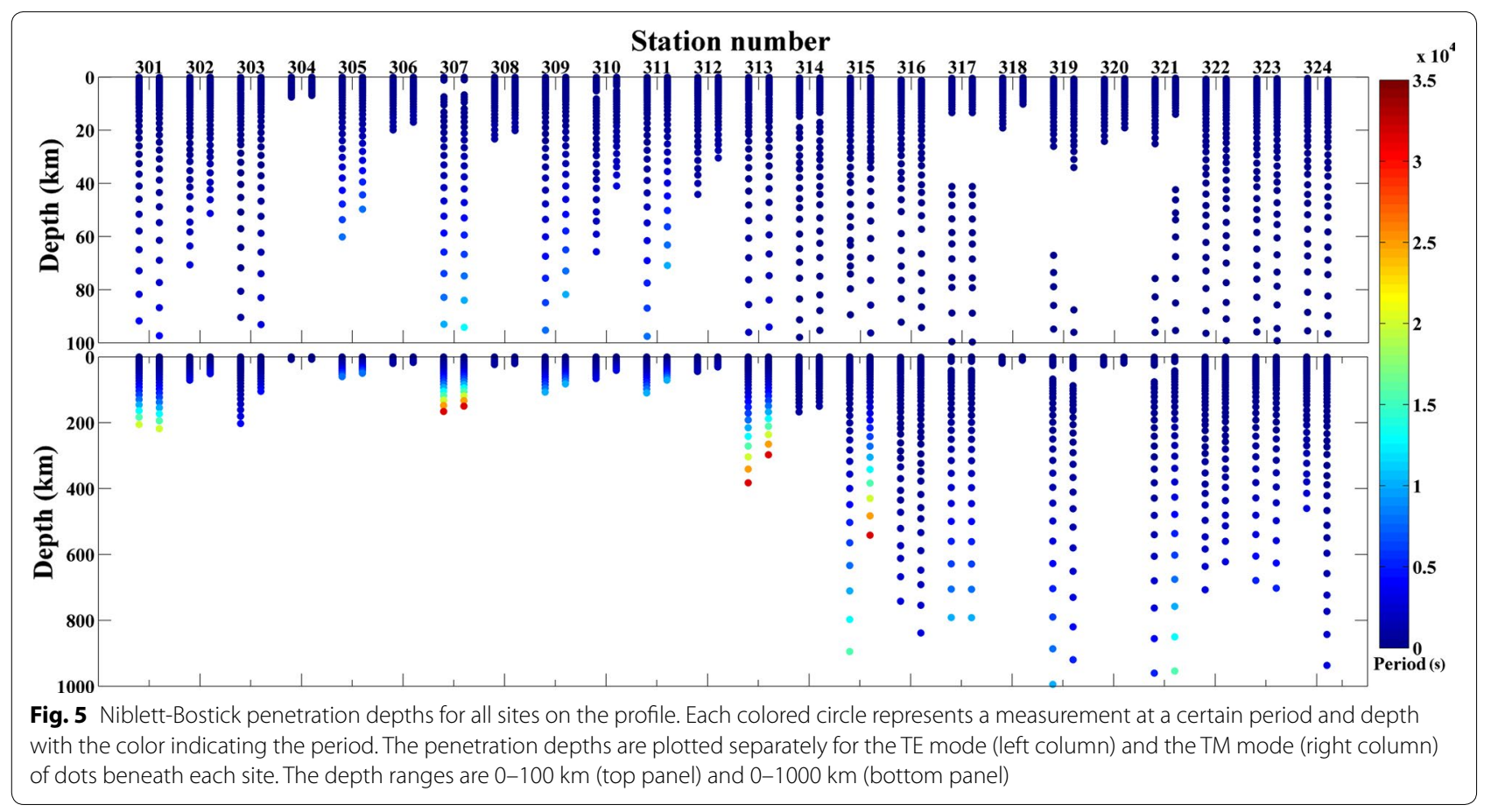

determine an appropriate smoothing operator, several inversions were performed using different regularization parameters. The tradeoff between the inverse smoothing operator $\tau$ and the model misfit is plotted in Fig. 6 as an $L$-curve (Hansen 1992). Since the smoothing operator at the knee of the $L$-curve is considered to be preferable, the value of 7 was chosen as an appropriate smoothing operator for the model. The inversion was carried out iteratively until it found the best fit with the observed data by projecting all stations onto a single profile and line. 


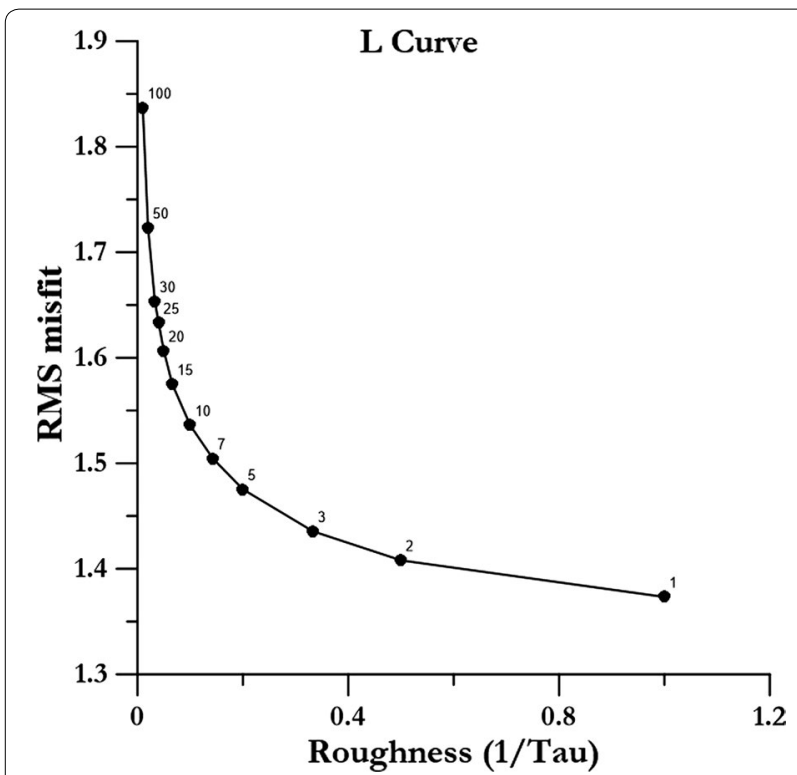

Fig. 6 Roughness against model fit tradeoff curve (L-curve) obtained for different smoothness regularization parameters $(\tau)$ versus RMS values for 2-D inversion models

The final RMS error of the inverted single profile model was 2.70 . To validate the final model, with two different strike directions along a single profile obtained from the joint inversion using TE, TM, and tipper data, separate models were run from two different geoelectric strike directions $\left(\mathrm{N} 5^{\circ} \mathrm{E}, \mathrm{N} 50^{\circ} \mathrm{E}\right)$ using parameters similar to that used for modeling the single profile (Fig. 8). The major features in the 2-D inversion models obtained along two profiles with different strike directions are similar to that obtained with a single profile using two different strike directions. The apparent resistivity and phase pseudosections of the observed and modeled single-profile, two-strike-direction data are shown in Fig. 7 to facilitate a comparative model assessment. The dots on the pseudo-sections correspond to data at different periods. In the apparent resistivity pseudo-sections of the TE and TM modes, the demarcation of conductive and resistive features can be easily recognized. The final geoelectric model obtained from the joint TE, TM and tipper data inversion is shown in Fig. 8, along with the RMS misfit of the joint inversion at each individual site listed at the top of the model. The RMS misfits for stations 316, 320 and 323 are high due to the misfit between the modeled and observed TE mode data, which may be due to current channeling at the edges of the geological bodies (Rao et al. 2014a) as shown in Fig. 1. In Fig. 9, observed and modeled data responses are shown, at representative stations covering major sections of the profile, for the model used in Fig. 8.

\section{Results and discussion}

Figure 8 shows the resistivity model derived from 2-D inversion of the MT data together with major identified surface geological features, in order to understand the relationship between tectonic and geological processes and the resistive structures. The geoelectric cross section over the $\mathrm{E}-\mathrm{W}$ profile across the Cambay rift basin reveals the different structural features beneath this region. The resistivity model shows significant contrasts $(\sim 1-10,000 \Omega-\mathrm{m})$ from west to east, indicating a rather heterogeneous subsurface structure. For the sake of convenient discussion, the major resistive and conductive features in Fig. 8 are denoted with alphanumerics (R1, $\mathrm{R} 2 \ldots \mathrm{C} 1, \mathrm{C} 2 \ldots$ etc.). Based on the resistivity variations across the profile at crustal depths, it is divided into two major segments, with the conductive features on the western side and resistive features on the eastern side.

The conductive layer $\mathrm{C} 2$, with widely varying conductance values of $\sim 300-1000 \mathrm{~S}$, is delineated between stations 303-313. This conductive feature (300-1000 S) is attributed to the Tertiary and Quaternary sediments deposited over the Cambay rift basin and particularly its western region. DSS and gravity studies (Kaila et al. 1990; Mishra et al. 1998; Dixit et al. 2010) have reported a maximum sediment thickness of $2-3 \mathrm{~km}$ over the ridges and 5-6 km over the depressions, and seismic velocities $(5.5-5.8 \mathrm{~km} / \mathrm{s})$ have suggested a past accumulation of sediments. The present MT study shows the presence of thick sediments $(1-5 \mathrm{~km})$ beneath the Cambay rift zone as denoted by $\mathrm{C} 2$, corroborating the DSS and gravity studies. The syn-rift event caused widespread volcanism to subdue the initial rifting effects. The Deccan basaltic lava eruption created a thick basaltic lava cover that formed the basement, which then accumulated a thick layer of marine and lagoonal fine clastic sediment between the Late Paleocene and Mid Miocene, until the rifting process ceased (Biswas 1987). The conductive features $\mathrm{C} 1 \mathrm{a}$ and $\mathrm{C} 1 \mathrm{~b}$ of $400-600 \mathrm{~S}$ conductance, observed at a depth of $\sim 6 \mathrm{~km}$, may be due to fluid emplacement at crustal depths. The thermal perturbations due to magmatic activity might have affected the composition and configuration of the crust during the Late Mesozoic in the form of a low-density layer, as mid-crustal emplacement of fractionated fluids spread throughout the regions of the western margin of the profile. The low-density and low-velocity crustal zone of these areas was found from gravity and DSS studies. Additionally, the mixing of rhyolitic and basaltic magmas may have occurred in the crust as the Cambay rift and Barmer basins connected during the Late Cretaceous (Kilaru et al. 2013). However, the combined appearance of low density, low velocity, and low resistivity supports the more likely scenario of fluid emplacement into crustal depths. 


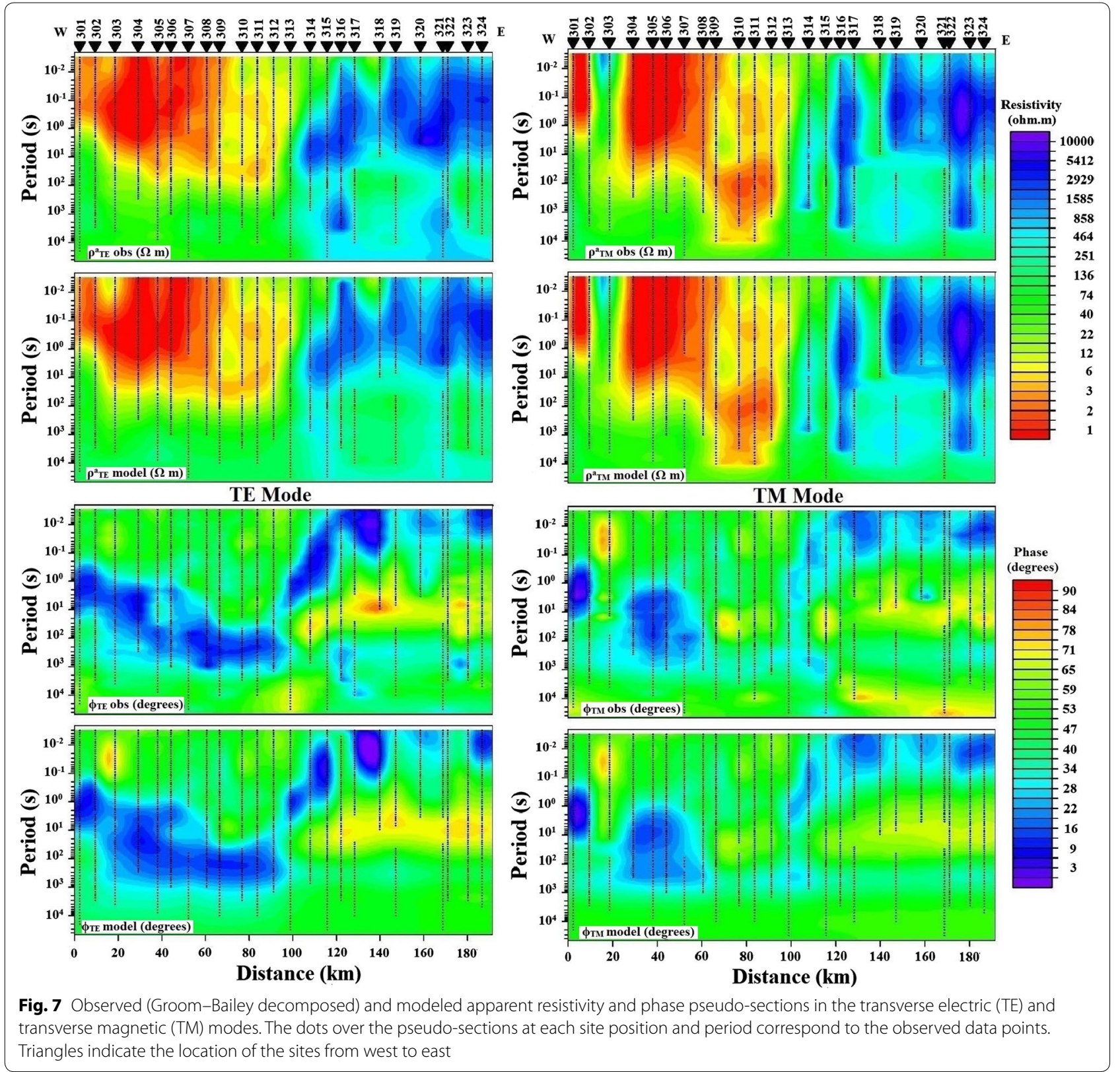

The outlined resistive features R1 and R6 ( $5000 \Omega-\mathrm{m})$ in the western part of the profile at depths of $\sim 2 \mathrm{~km}$ may relate to the Precambrian basement. To validate the presence of R1 and R6, a sensitivity analysis was carried out. The R1 and R6 features were replaced with the $50 \Omega-\mathrm{m}$ resistivity of the surrounding formation. The model responses with and without these resistive features are shown in Additional file 1: Fig. S2a, b along with the observed data. After the removal of R1 at stations 301302 and R6 at 306-308, a larger misfit was calculated at these sites between the model and the observed data. A decrease in apparent resistivity and an increase in the phase are shown after the removal of the resistors for different periods, of $>1 \mathrm{~s}$ for R1 and of $>100 \mathrm{~s}$ for R6. This sensitivity test indicates that the detection of the R 1 and R6 resistors is robust, and they can be considered as reliable features. R1 and R6 may be related to the pre-existing Precambrian Malani igneous suite basement, which did not significantly revive due to the Deccan basaltic eruption. The Precambrian basement is delineated beneath stations 301-307, excepting station 303. This station is located adjacent to the junction of the Luni river and the Rann of Kutch. Bajpai et al. (2001) identified a shallow NE-SW fault system along the Luni river. This could 


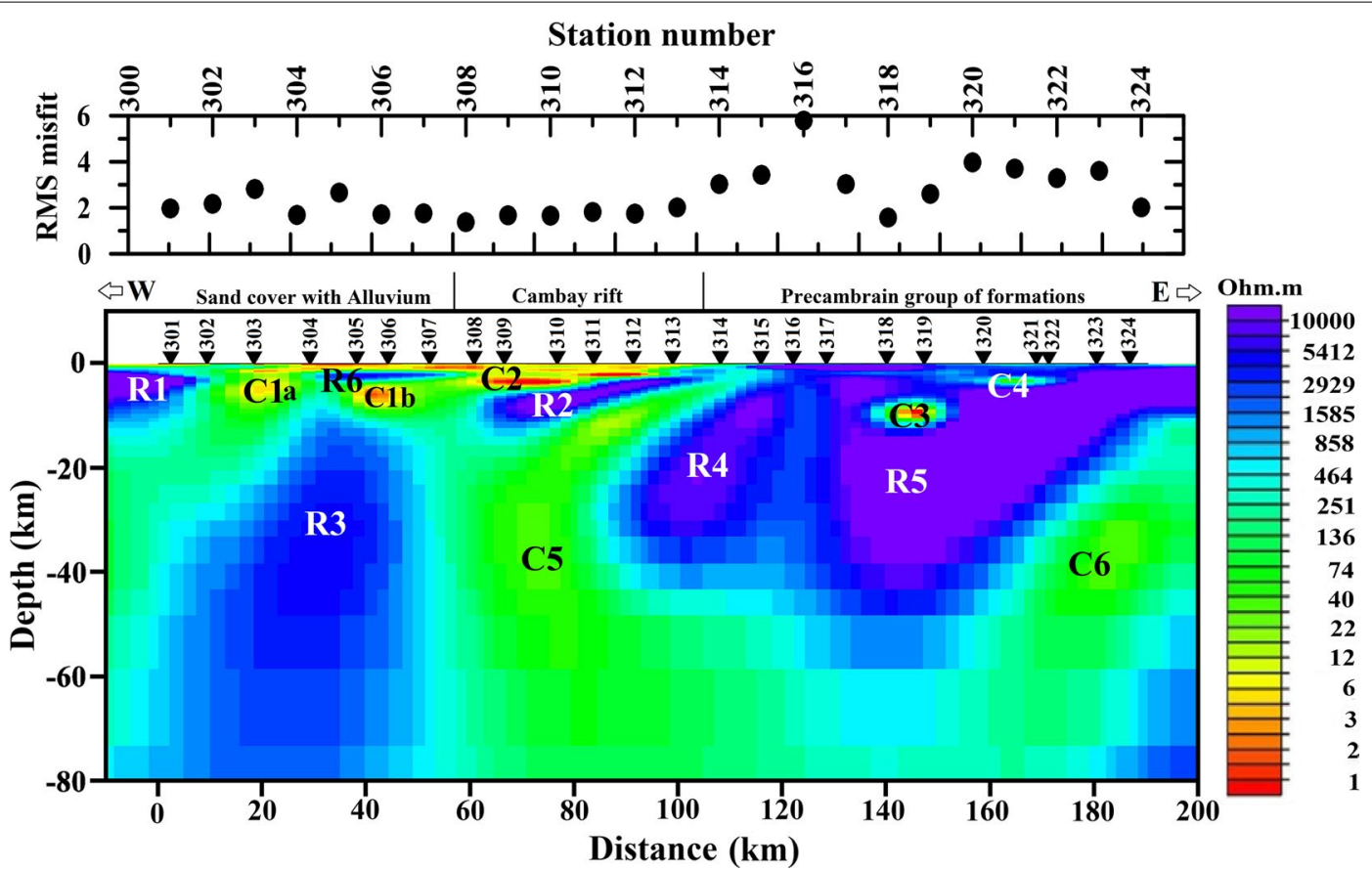

Fig. 8 2-D smooth inversion model of the profile (vertical exaggeration 1.0). The triangles indicate the location of the sites used from west to east by indicating geological formations across the profile. The RMS values of the joint inversion with respect to the final model at each individual site are shown in the top panel
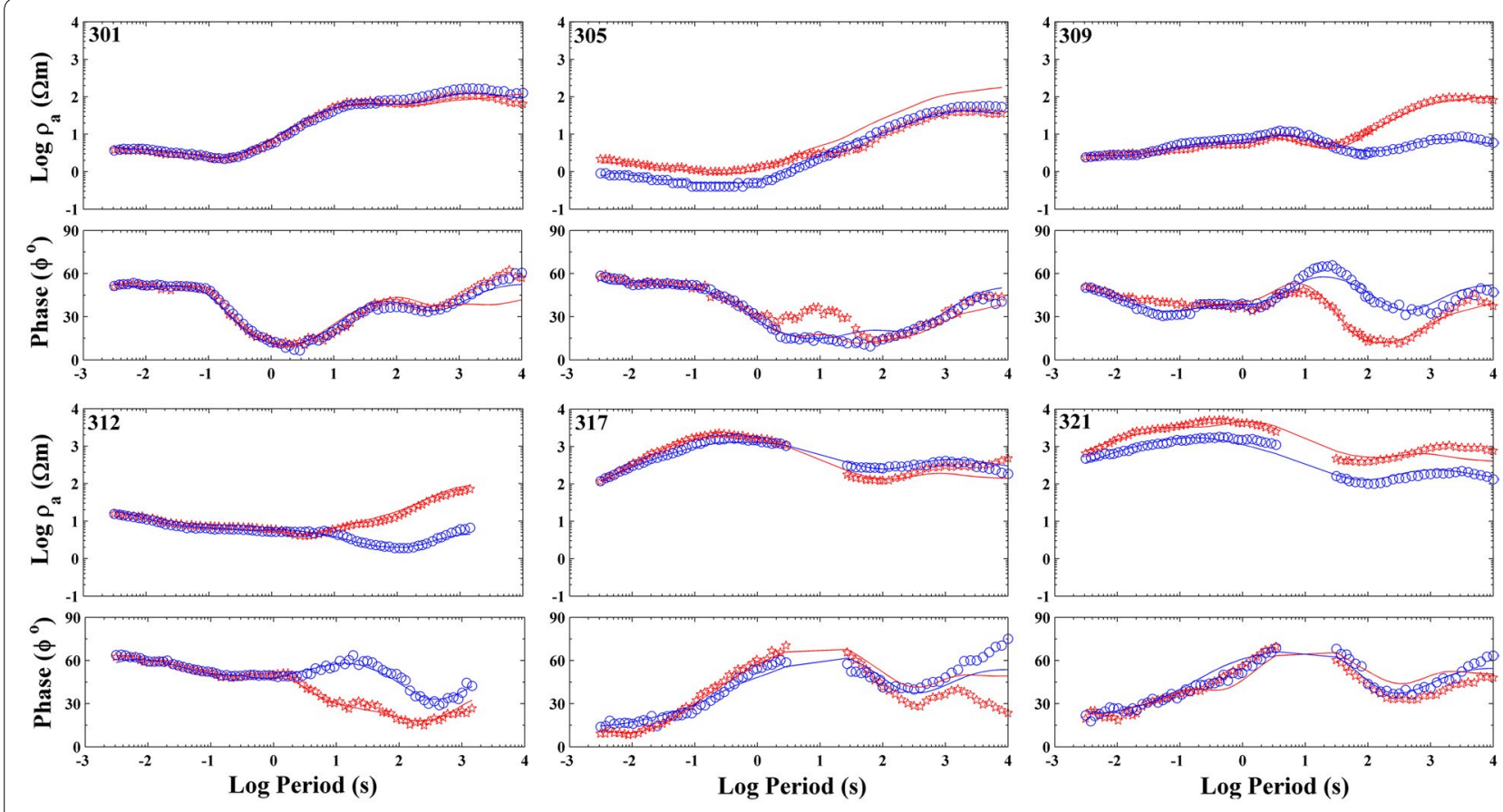

मे TE Observed $\bigcirc$ TM Observed — TE computed - TM computed

Fig. 9 2-D inversion data fit to the observed data and computed responses for representative stations. Open red star represents TE observed response, open blue circle represents TM observed response, red solid line represents TE computed response, and the blue solid line represents TM computed response 
be the cause for the absence of a basement at station 303 as indicated in the sounding curve as a large difference between the TE and TM modes up to a period of $1 \mathrm{~s}$. The eastern part of the profile shows highly resistive features denoted as R2, R4 and R5 (5000-10,000 $\Omega$-m) beneath stations $313-324$. Though $\mathrm{R} 2$ is identified beneath station 313 , it extends toward the west to station 309 , at crustal depths of $15-20 \mathrm{~km}$ beneath $\mathrm{C} 2$, whereas the resistive features R4 and R5 extend to upper mantle depths. These stations, located over the Precambrian Aravalli and Delhi group formations, consist primarily of intensely folded, deformed and metamorphosed Proterozoic rocks deposited over the Archean basement. The Aravalli-Delhi fold belt is one of the major Precambrian tectonic trends in western India and represents the oldest orogenic cycle of metamorphic belts in the western margin of India. It has witnessed four major regional tectono-magmatic and metamorphic events from $\sim 3000 \mathrm{Ma}$ to $\sim 750 \mathrm{Ma}$ (Rao et al. 2000). The reactivation of these tectonic trends controlled the major fault systems of the WCMI. Thus, the delineated high resistivity features R2, R4 and R5 may be due to the high-grade metamorphic rocks of the Aravalli and Delhi group of formations. The resistive feature R2 extends beneath the Cambay rift basin and may indicate an extension of these formations toward the western margin.

The crustal conductors $\mathrm{C} 3$ and $\mathrm{C} 4$ are delineated within the Aravalli and Delhi group formations. A sensitivity test was carried out to validate these conductors at crustal depths within the resistive formations. These conductors were replaced with the surrounding formation resistivity of 10,000 $\Omega-\mathrm{m}$. The model responses with and without the conductors are shown in Additional file 1: Fig. S2c. A larger misfit was calculated between the model and the observed data after replacement. The increase in apparent resistivity and a decrease in phase seen for most of the periods support the existence of the conductors. The sensitivity test indicates that the detection of the conductors is robust and that they can be reliably considered as features of the final model. Conductive features, in general, can be explained at crustal depths with various subsurface mechanisms, such as the presence of fluids in interconnected pore spaces (Hyndman and Shearer 1989), high permeability due to fault gouge, interconnected graphite, sulfides, and oxides (Glover and Vine 1992), and magmatic underplating (Wannamaker et al. 2008). Graphite can be immediately ruled out, however, as there are no reports of its presence in the study area. The Aravalli-Delhi fold belt consists of polyphase metamorphic rocks and has witnessed major tectono-magnetic, metamorphic events and is associated with numerous transverse, oblique faults and shear zones (Rao et al. 2000). However, the presence of fluids and their permeability within faults, as well as interconnected sulfides along the grain boundaries occurring during different metamorphic phases, could be possible mechanisms that formed the $\mathrm{C} 3$ and $\mathrm{C} 4$ conductive features. Thus, the conductors $\mathrm{C} 1 \mathrm{a}$ and $\mathrm{C} 1 \mathrm{~b}$ were formed in the Cambay rift due to the emplacement of fluids, and the conductors C3 and C4 in Aravalli-Delhi formations were formed due to sulfide mineralization during various metamorphic phases and the presence of fluids within the fault and shear zones.

The resistive feature R3 (2500-5000 $\Omega$-m) may be due to the felsic-intermediate granulitic composition of igneous intrusives, observed across the Son-Narmada region of central India (Naganjaneyulu and Santosh 2010 and references therein). This is a signature of the dominant distribution of the felsic components of polyphase metamorphic rocks and their granulitic composition. The clear variation of resistivities from R3 (2500-5000 $\Omega-\mathrm{m}$ ) to C5 (30-100 $\Omega-\mathrm{m})$ can be seen beneath station 307, and its vertical drop may represent the fault between two separate formations. The Cambay basin is well known to be bounded by two steep faults on the eastern and western margins and divided into different crustal blocks. The seismic activity over the region suggests that these deep faults may be currently active (Kaila et al. 1981; Biswas 1987). The observed vertical dipping feature may be related to the western margin of the Cambay rift zone, whereas the eastern margin of the basin is dipping toward NE-SW at R4, which may represent a half-graben structure.

The conductors C5 and C6 (30-100 $\Omega-\mathrm{m})$ lie beneath the Cambay rift zone and Aravalli-Delhi formations, respectively. These conductors are isolated at shallow, $\sim 20 \mathrm{~km}$ depths but are connected at a depth of $\sim 60 \mathrm{~km}$. The possible subsurface mechanisms for the moderate conductors are explained below in detail. In general, anomalies in high electrical conductivity can be ascribed to the presence of fluids, partial melt, graphite and/or sulfide mineralization. In general, partial melt generation needs a minimum temperature of $700{ }^{\circ} \mathrm{C}$ (Thompson 1992). The Cambay rift zone geotherm presented by Kumar et al. (2016) shows that temperatures do not exceed $700{ }^{\circ} \mathrm{C}$ at the depth of $\sim 30 \mathrm{~km}$. This indicates that temperatures at depths $<30 \mathrm{~km}$ are not enough to produce partial melt, and so partial melting is unlikely to be an appropriate mechanism for forming the $\mathrm{C} 5$ and C6 conductors. The high density of $3.1 \mathrm{~g} / \mathrm{cm}^{3}$, seismic velocity of $7.3-7.4 \mathrm{~km} / \mathrm{s}$, and conductivity of $30-70 \Omega-\mathrm{m}$ in the lower crust can be explained by magmatic intrusions into the crust due to underplating. In general, the release of fluids migrating upwards during underplating results in lower resistivities. The wide correlation between the mantle plume and flood basalts (Courtillot 
et al. 1988; Raval and Veeraswamy 2000; Veeraswamy and Raval 2004; Isozaki 2009) suggests a huge basaltic eruption occurred from the rising mantle plume during the interaction. The buoyant basaltic melt rose to the surface due to its low density, and when it reached the neutral density point at the Moho, underplating occurred raising the Moho depth. Due to a density contrast between the melts and lower crust, some portion of the melts continued to migrate upward and penetrate the lower crust. After reaching another neutral point at the mafic-felsic crustal boundary, the melts were trapped and crystallized into layer intrusions. Tectonic processes could then have resulted in an eruption of the trapped melts and processes like fracturing, bubbling, and vaporizing, contributing to the reduction of melt density, which led to a basaltic eruption on the surface. Depending on temperature and pressure conditions and the presence of fluids, the mafic components of the melt would be altered into metamorphic assemblages, including amphibolites and meta-gabbros (Naganjaneyulu and Santosh 2010 and references therein). The heat flow values in this part of the Cambay rift zone are higher at $75-96 \mathrm{~mW} / \mathrm{m}^{2}$, with mean $83 \pm 7 \mathrm{~mW} / \mathrm{m}^{2}$, than that of stable continental areas of whose value is $\sim 46 \mathrm{~mW} / \mathrm{m}^{2}$ (Verma et al. 1968; Gupta et al. 1970; Gupta 1981), a difference that may alter the melts to garnet-bearing high-pressure granulites. A reflective lower crust, with average velocities of 7.4$7.8 \mathrm{~km} / \mathrm{s}$, is observed in the Baikal and Kenya rift zones, suggesting the intrusion of mafic material into the crust. Lower average crustal velocities of $7.2-7.5 \mathrm{~km} / \mathrm{s}$ observed from seismic studies within the Cambay rift zone (Kaila et al. 1990; Dixit et al. 2010) are nevertheless higher than the expected normal lower crustal velocities beneath this area, which is interpreted as due to magmatic underplating of the crust. These intrusions may partially compensate for the crustal thinning caused by lithosphere extension during the rifting process. These are typical signatures related to rift systems as reported over the Baikal rift zone, Walvis Ridge rift basin and Rio Grande rift system (Hermance and Pedersen 1980; Morley 1994; Smith 1994; Birt et al. 1997; Zhao et al. 2006; Thybo and Artemieva 2013; Jegen et al. 2016). The conductivity observed for the C5 and C6 conductors at depths of $<30 \mathrm{~km}$ are related to underplating, and at depths $>30 \mathrm{~km}$ may be due to a different subsurface mechanism. Kumar et al. (2016) reported a 10\% drop in shear velocity over the Cambay rift zone and inferred that little more than $1 \%$ of the partial melt in the asthenosphere and identified temperature contrasts provided a realistic explanation for the shear velocity drop. Schilling et al. (1997) suggested that the melt fraction of $>3 \%$ is sufficient to explain low resistivities, assuming melt interconnectivity from MT studies and the presence of a zone of low seismic velocities at similar depths and high heat flow values $\left(>100 \mathrm{~mW} / \mathrm{m}^{2}\right)$. A bulk resistivity of $3 \Omega-\mathrm{m}$ requires a melt fraction of $\sim 5-14 \%$ (Unsworth et al. 2005). Dong et al. (2015) suggested that the $0.2-1 \%$ melt fraction with a geotherm $>800{ }^{\circ} \mathrm{C}$ is sufficient to allow hydrous melting at upper mantle depths in order to obtain moderate conductivities. The presence of little more than $1 \%$ melt and a geotherm range $800-1200{ }^{\circ} \mathrm{C}$ (Kumar et al. 2016) may therefore be a possible mechanism for conductivities observed at depths $>30 \mathrm{~km}$ of C5 and C6 conductors, corroborating the $\sim 50 \Omega-\mathrm{m}$ conductivities observed for the Baikal rift zone at depths of $40-60 \mathrm{~km}$ (Berdichevsky et al. 1980). Thus, the moderate conductive features C5 and $\mathrm{C6}$ resulted from underplating and the partial melts generated by plume-lithosphere interactions. It is possible that thermal perturbations associated with plume activity might have affected the composition of the lithosphere resulting in the emplacement of partially molten material into crustal depths. The depth variations of conductor C5 across the profile imply that the effects of the plume were not uniform across it, and most of the upper mantle of the Cambay rift zone was altered. The lithospheric-asthenospheric boundary (LAB) cannot be resolved in the model as Kumar et al. (2016) reported at $\sim 60 \mathrm{~km}$ beneath rift zone and $\sim 110 \mathrm{~km}$ on either side of the rift. A transition in seismic velocity was observed at those depths, whereas a transition in electrical resistivity was not observed to depths of $\sim 80 \mathrm{~km}$. Depth constraints and a lack of resistivity contrast in the model make it impossible to delineate the electrical LAB.

\section{Conclusions}

Magnetotelluric studies across the northern Cambay basin have identified thick $\sim 1000 \mathrm{~S}$ conductive sediments, becoming shallower $(\sim 400 \mathrm{~S})$ toward the western part of the profile. A moderate conductive zone (30-100 $\Omega-\mathrm{m})$ is shown, representing underplating and partial melt emplacement, which may have been caused by plume-lithosphere interactions. The crust beneath the western part of the profile shows an igneous granitic intrusion. Delineated crustal conductors may be related to the presence of fluids associated with fault and shear zones and sulfide mineralization during different stages of metamorphism. Precambrian rocks of the Aravalli and Delhi formations with resistivity of $5000-10,000 \Omega-\mathrm{m}$ were identified on the eastern side of the rift basin. The eastern margin of the rift basin dips in the NE-SW direction, representing a half-graben structure. Plume interaction has significantly altered the lithosphere, and deciphering information about the LAB is not possible due to depth constraints. 


\section{Additional file}

Additional file 1: Figure $\mathbf{S 1}$. Tensor decomposition results a pseudosection of RMS misfit, $\mathbf{b}$ shear and twist angles at each station. Figure $\mathbf{S 2}$. Results of sensitivity tests $\mathbf{a}$ for R6 $\mathbf{b}$ for R2 and $\mathbf{c}$ for $\mathrm{C} 3$ and C4.

\section{Abbreviations}

BBMT: broadband magnetotellurics; DSS: deep seismic sounding; DVP: Deccan volcanic province; LMT: long period magnetotellurics; LAB: lithospheric-asthenospheric boundary; MT: magnetotellurics; NSV: near-surface shear velocities; TE: transverse electric; TM: transverse magnetic; WCMI: western continental margin of India.

\section{Authors' contributions}

ND carried out the analysis and drafted the initial text. CKR gave very important suggestions at various stages of the work, evaluated the initial text for scientific content and co-drafted the manuscript. AK helped in data acquisition and processing. All authors read and approved the final manuscript.

\section{Author details}

${ }^{1}$ Dr. K. S. Krishnan Geomagnetic Research Laboratory, IIG, Allahabad, India.

${ }^{2}$ Indian Institute of Geomagnetism, New Panvel, Navi Mumbai, India.

\section{Acknowledgements}

CKR acknowledges the Ministry of Earth Sciences, Government of India for funds received through the Project (MOES/P.O (Seismo)/1(130)/2011)). ND is thankful to the Department of Science and Technology (DST), India, for providing a research fellowship. CKR is thankful to Alan Jones for providing the multi-site, multi-frequency decomposition code of McNeice and Jones. S.G. Gokarn is acknowledged for suggestions and corrections in the manuscript. Thanks are also due to the Director of the Indian Institute of Geomagnetism for the necessary permissions and approvals. We thank two anonymous reviewers for their critical comments which made significant improvement in the presentation of the manuscript.

\section{Competing interests}

The authors declare that they have no competing interests.

\section{Availability of data and materials}

The data utilized in this work cannot be shared unless permission is granted by agency sponsoring the work. For more details about the availability of the data, individuals can contact the authors.

\section{Consent for publication}

Not applicable.

\section{Ethics approval and consent to participate}

Not applicable.

\section{Funding}

The work has been carried out under project (MOES/P.O (Seismo)/1(130)/2011) sponsored by Ministry of Earth Sciences, Govt. of India.

\section{Publisher's Note}

Springer Nature remains neutral with regard to jurisdictional claims in published maps and institutional affiliations.

Received: 4 May 2017 Accepted: 27 September 2017

Published online: 06 October 2017

\section{References}

Abdul Azeez KK, Unsworth MJ, Patro PK, Harinarayana T, Sastry RS (2013) Resistivity structure of the Central Indian tectonic zone (CITZ) from multiple magnetotelluric (MT) profiles and tectonic implications. Pure Appl Geophys 1(70):2231-2256. doi:10.1007/s00024-013-0649-y
Abdul Azeez KK, Patro PK, Harinarayana T, Sarma SVS (2017) Magnetotelluric imaging across the tectonic structures in the eastern segment of the Central Indian Tectonic Zone: preserved imprints of polyphase tectonics and evidence for suture status of the Tan Shear. Precambr Res 298:325340. doi:10.1016/j.precamres.2017.06.018

Bajpai VN, Saha Roy TK, Tandon SK (2001) Subsurface sediment accumulation patterns and their relationships with tectonic lineaments in the semi-arid Luni river basin, Rajasthan, Western India. J Arid Environ 48:603-621. doi:10.1006/jare.2000.0766

Berdichevsky MN, Vanyan LL, Kuznetsov VA, Levadny VT, Mandelbaum MM, Nechaeva GP, Okulessky BA, Shilovsky PP, Shpak IP (1980) Geoelectrical model of the Baikal region. Phys Earth Planet Inter 22:1-11

Bhattacharya GC, Chaubey AK (2001) Western Indian Ocean-a glimpse of the tectonic scenario. In: Sen Gupta R, Desa E (eds) The Indian Ocean—a perspective. IBH, New Delhi, Oxford, pp 691-729

Birt CS, Maguire PKH, Khan MA, Thybo H, Keller GR, Patel J (1997) The influence of pre-existing structures on the evolution of the southern Kenya Rift valley: evidence from seismic and gravity studies. Tectonophysics 78:211-242. doi:10.1016/S0040-1951(97)00105-4

Biswas SK (1982) Rift basins in the western margin of India and their hydrocarbon prospects. AAPG Bull 66:1497-1513

Biswas SK (1987) Regional tectonic framework, structure and evolution of the western marginal basins of India. Tectonophysics 135:307-327

Bostick FX (1977) A simple almost exact method of MT analysis. Workshop on electrical methods in geothermal exploration, Contract 14080001-8-359, US Geol Surv, Reston, VA

Campbell IH, Griffiths RW (1990) Implications of mantle plume structure for the evolution of flood basalts. Earth Planet Sci Lett 99:79-93

Chaubey AK, Dyment J, Bhattacharya GC, Royer JY, Srinivas K, Yatheesh V (2002) Paleogene magnetic isochrons and paleo-propagators in the Arabian and eastern Somali basins, Northwest Indian Ocean. In: Clift PD, Kroon D, Gaedicke C, Craig J (eds) The tectonic and climatic evolution of the Arabian Sea region, vol 195. Geological Society, London, pp 71-85 (Special Publications)

Courtillot V, Fraud G, Maluski H, Vandamme D, Moreau MG, Besse J (1988) Deccan flood basalts and the Cretaceous-Tertiary boundary. Nature 333:843-846

Dixit MM, Tewari HC, Rao CV (2010) Two-dimensional velocity model of the crust beneath the South Cambay Basin, India from refraction and wide-angle reflection data. Geophys J Int 181:635-652. doi:10.1111/j.1365-246X.2010.04539.x

Dong Z, Tang J, Unsworth M, Chen X (2015) Electrical resistivity structure of the upper mantle beneath northeastern China: implications for rheology and the mechanism of craton destruction. J Asian Earth Sci 100:115-131. doi:10.1016/j.jseaes.2015.01.008

Glover PWJ, Vine FJ (1992) Electrical conductivity of carbon bearing granulite at raised temperatures and pressures. Nature 360:723-726

Gokarn SG, Rao CK, Gupta G, Singh BP, Yamashita M (2001) Deep crustal structure in central India using magnetotelluric studies. Geophys J Int 144:685-694

Gupta ML (1981) Surface heat flow and igneous intrusion in the Cambay Basin, India. J Volcanol Geotherm Res 10:279-292

Gupta ML, Verma RK, Hamza VM, Rao GV, Rao RUM (1970) Terrestrial heat flow and tectonics of Cambay Basin, India. Tectonophysics 10:147-163

Hansen PC (1992) Analysis of discrete ill-posed problems by means of the L-curve. SIAM (Soc Ind Appl Math) Rev 34:561-580. doi:10.1137/1034115

Hermance JF, Pedersen J (1980) Deep structure of the Rio Grande rift: a magnetotelluric interpretation. J Geophys Res 85:3899-3912. doi:10.1016/j. gr.2008.12.007

Hyndman RD, Shearer PM (1989) Water in the lower continental crust: modeling magnetotelluric and seismic reflection results. Geophys J Int 98:343-365

Isozaki Y (2009) Illawarra Reversal: the fingerprint of a superplume that triggered Pangean breakup and the end-Guadalupian (Permian) mass extinction. Gondwana Res 15:421-432. doi:10.1016/j.gr.2008.12.007

Jegen M, Avdeeva A, Berndt C, Franz G, Heincke B, Hölz S, Neska A, Marti A, Planert L, Chen J, Kopp H, Baba K, Ritter O, Weckmann U, Meqbel N, Behrmann J (2016) 3-D magnetotelluric image of offshore magmatism at the Walvis Ridge and rift basin. Tectonophysics 683:98-108. doi:10.1016/j. tecto.2016.06.016

Jones AG (1983) On the equivalence of the "Niblett" and "Bostick" transformations in the magnetotelluric method. J Geophys 53:72-73 
Jones AG (1992) Electrical properties of the lower continental crust. In: Fountain DM, Arculus R, Kay RW (eds) Continental lower crust. Elsevier, Amsterdam, pp 81-144

Jones AG (2006) Electromagnetic interrogation of the anisotropic Earth: looking into the Earth with polarized spectacles. Phys Earth Planet Inter 158:281-291. doi:10.1016/j.pepi.2006.03.026

Jones AG, Jödicke H (1984) Magnetotelluric transfer function estimation improvement by a coherence-based rejection technique. Paper presented at 54th annual meeting, society of exploration geophysics, Atlanta, GA

Jones AG, Chave AD, Auld D, Bahr K, Egbert G (1989) A comparison of techniques for magnetotelluric response function estimation. J Geophys Res 94:14201-14213. doi:10.1029/JB094iB10p14201

Kaila KL, Krishna VG, Mall DM (1981) Crustal structure along MehmadabadBillimora profile in the Cambay basin, India, from deep seismic soundings. Tectonophysics 76:99-130. doi:10.1016/0040-1951(81)90255-9

Kaila KL, Tewari HC, Krishna VG, Dixit MM, Sarkar D, Reddy MS (1990) Deep seismic sounding studies in the north Cambay and Sanchore basins, India. Geophys J Int 103:621-637. doi:10.1111/j.1365-246X.1990.tb05676.X

Kilaru S, Goud BK, Rao VK (2013) Crustal structure of the western Indian shield: model based on regional gravity and magnetic data. Geosci Front 4:717-728. doi:10.1016/j.gsf.2013.02.006

Kumar P, Sen G, Mandal P, Sen MK (2016) Shallow lithosphere-asthenosphere boundary beneath Cambay Rift Zone of India: inferred presence of carbonated partial melt. J Geol Soc India 88:401-406

Mackie RL, Madden TR (1993) Three-dimensional magnetotelluric inversion using conjugate gradients. Geophys J Int 115:215-229

McNeice GW, Jones AG (2001) Multisite, multifrequency tensor decomposition of magnetotelluric data. Geophysics 66(1):158-173

Mishra DC, Gupta SB, Tiwari VM (1998) A geotransect from Dharimanna to Billimora across the Cambay and Narmada-Tapti rift basins, India. Int Geol Rev 40:1007-1020

Mohan M (1995) Cambay basin—a promise of oil and gas potential. J Paleonto Soc India 40:41-47

Morley CK (1994) Interaction of deep and shallow processes in the evolution of the Kenya rift. Tectonophysics 236:81-91

Naganjaneyulu K, Santosh M (2010) The central Indian tectonic zone: a geophysical perspective on continental amalgamation along a Mesoproterozoic suture. Gondwana Res 18:547-564. doi:10.1016/j.gr.2010.2.017

Negi BS (1951) Gravity and magnetic surveys in subsurface structures in the Borsad area, Kheda district. Geol Surv India Rept (unpublished)

Negi JG, Agrawal PK, Singh AP, Pandey OP (1992) Bombay gravity high and eruption of Deccan flood basalts (India) from a shallow secondary plume. Tectonophysics 206:341-350

Niblett ER, Sayn-Wittgenstein C (1960) Variation of electrical conductivity with depth by the magnetotelluric method. Geophysics 25:998-1008

Panda PK, Dutta HC (1985) Prospective geothermal fields in Cambay Basin, India. In: International symposium on geothermal Energy, pp 537-538

Patro PK, Sarma SVS (2016) Evidence for an extensive intrusive component of the Deccan Large Igneous Province in the Narmada-Son Lineament region, India from three-dimensional magnetotelluric studies. Earth Planet Sci Lett 451:168-176. doi:10.1016/j.epsl.2016.07.005

Qureshi MN (1964) A geological analysis of Bouguer anomaly of peninsular India. Proc Nat Inst Sci India Part A 30:675-688

Rao NDJ (1968) An interpretation of gravity data of Cambay basin. ONGC Bul 4:74-80

Rao W, Prasad BR, Reddy PR, Tewari HC (2000) Evolution of Proterozoic Aravalli-Delhi Fold Belt in the northwestern Indian Shield from seismic studies. Tectonophysics 327:109-130

Rao CK, Ogawa Y, Gokarn SG, Gupta G (2004) Electromagnetic imaging of magma across the Narmada-Son lineament, central India. Earth Planets Space 56:229-238. doi:10.1186/BF03353405

Rao CK, Jones AG, Moorkamp M, Weckmann U (2014a) Implications for the lithospheric geometry of the lapetus suture beneath Ireland based on electrical resistivity models from deep-probing magnetotellurics. Geophys J Int 198:737-759. doi:10.1093/gji/ggu136

Rao CK, Selvaraj C, Gokarn SG (2014b) Deep electrical structure over the igneous arc of the Indo Burman Orogen in Sagaing province, Myanmar from magnetotelluric studies. J Asian Earth Sci 94:68-76. doi:10.1016/j. jseaes.2014.08.016
Rao KM, Ravi Kumar M, Rastogi BK (2015) Crust beneath the northwestern Deccan volcanic province, India: evidence for uplift and magmatic underplating. J Geophys Res Solid Earth 120:3385-3405. doi:10.1002/20 14JB011819

Raval U, Veeraswamy K (2000) The radial and linear modes of interaction between mantle plume and continental lithosphere: a case study from western India. J Geol Soc India 56:525-536

Rodi W, Mackie RL (2001) Nonlinear conjugate gradients algorithm for 2-D magnetotelluric inversion. Geophysics 66:174-187

Roy Chowdhury K, Hargraves RB (1981) Deep seismic sounding in India and the origin of continental crust. Nature 291:648-650 doi:10.1038/291648a0

Royer JY, Chaubey AK, Dyment J, Bhattacharya GC, Srinivas K, Yatheesh V Ramprasad T (2002) Paleogene plate tectonic evolution of the Arabian and Eastern Somali basins. In: Clift PO, Kroon D, Gaedicke C, Craig J (eds) The tectonic and climatic evolution of the Arabian Sea region, vol 195. Geological Society, London, pp 7-23 (special publications)

Schilling FR, Partzsch MG, Brasse H, Schwarz G (1997) Partial melting below the magmatic arc in the central Andes deduced from geoelectromagnetic field experiments and laboratory data. Phys Earth Planet Inter 103:17-31

Singh B, Prajapati SK, Mishra DC (2003) Presence of anomalous crustal root beneath Saurashtra peninsula: inference from gravity modeling. J Geophys 24:25-29

Smith M (1994) Stratigraphic and structural constraints on mechanisms of active rifting in the Gregory rift, Kenya. Tectonophysics 236:3-22

Sonam, Dhannawa BS, Kumar V (2013) Trend of geothermal gradient from bottom hole temperature studies in South Cambay basin (Narmada Broach Block). In: 10th Biennial internat conference and exposition, SPG, P386, Kochi

Storey M, Mahoney JJ, Saunders AD, Duncan RA, Kelley SP, Coffin MF (1995) Timing of hot spot-related volcanism and the breakup of Madagascar and India. Science 267:852-855. doi:10.1126/science.267.5199.852

Tewari HC, Dixit MM, Sarkar D, Kaila KL (1991) A crustal density model across the Cambay basin, India, and its relationship with the Aravallis. Tectonophysics 194:123-130

Tewari HC, Dixit MM, Sarkar D (1995) Relationship of the Cambay rift basin to the Deccan volcanism. J Geodyn 20:85-95

Tewari HC, Dixit MM, Rao NM, Venkateswarlu N, Rao VV (1997) Crustal thickening under the palaeo-meso-Proterozoic Delhi Fold Belt in northwestern India: Evidence from deep reflection profiling. Geophys J Int 129:657-668

Thompson AB (1992) Metamorphism and fluids. In: Brown GC, Hawkesworth CJ, Wilson RCL (eds) Understanding the Earth. Cambridge University Press, Cambridge

Thybo H, Artemieva IM (2013) Moho and magmatic underplating in continental lithosphere. Tectonophysics 609:605-619. doi:10.1016/j. tecto.2013.05.032

Unsworth MJ, Jones AG, Wei W, Marquis G, Gokarn SG, Spratt JE, The INDEPTHMT team (2005) Crustal rheology of the Himalaya and Southern Tibet inferred from magnetotelluric data. Nature 438:78-81. doi:10.1038/ nature04154

Veeraswamy K, Raval U (2004) Chipping of cratons and breakup along mobile belts of a supercontinent. Earth Planets Space 56:491-500. doi:10.1186/ BF03352508

Verma RK, Gupta ML, Hamza VM, Rao GV, Rao RUM (1968) Heat flow and crustal structure near Cambay, Gujarat, India. Bull Natl Geophys Res Inst 6:153-166

Wannamaker PE, Hasterok DP, Johnston JM, Stodt JA, Hall DB, Sodergren TL, Pellerin L, Maris V, Doerner WM, Groenewold KA, Unsworth MJ (2008) Lithospheric dismemberment and magmatic processes of the Great Basin-Colorado Plateau transition, Utah, implied from magnetotellurics. Geochem Geophys Geosyst 9:Q05019. doi:10.1029/2007GC001886

White RS, McKenzie DP (1989) Magmatism at rift zones: the generation of volcanic continental margins and flood basalts. J Geophys Res 94:7685-7729

Zhao D, Lei J, Inoue T, Yamada A, Gao SS (2006) Deep structure and origin of Baikal rift zone. Earth Planet Sci Lett 243:681-691. doi:10.1016/j. epsl.2006.01.033 